\title{
СПОСОБИ НЕПОВНОГО ДОТРИМАННЯ ТАБУ В КОМУНІКАЦЇ̈
}

Єловська Ю. В. Способи неповного дотримання табу в комунікації.

У статті розглядається проблема табу в комунікації. Подано класифікацію способів неповного дотримання табу на матеріалі українського мовлення. Зроблено спробу виокремити найчастотніші засоби уникнення табу в побутовому спілкуванні й виявити вплив табу на результативність комунікативної взаємодії.

Ключові слова: табу, комунікація, евфемізм, Інтернет-комунікація

Еловская Ю. В. Способы неполного соблюдения табу в коммуникации.

В статье рассматривается проблема табу в коммуникации. Предложена классификация способов неполного соблюдения табу на материале речи украинцев. Сделана попытка выделения наиболее часто употребимых средств избегания табу в бытовом общении и выявления их влияния на результативность коммуникативного взаимодействия.

Ключевые слова: табу, коммуникация, эвфемизм, Интернет-коммуникация 
Yelovska Yu. Methods of incomplete taboo compliance in communication.

This paper deals with the problem of taboo in communication. The article classifies the methods of incomplete taboo compliance on the material of Ukrainian speech practice. An attempt is made to distinguish the most frequent means of taboo avoiding in everyday communication and identify the taboo impact on the efficiency of communicative interaction.

Key words: taboo, communication, euphemism, Internet communication

Процес спілкування в різних його проявах $є$ предметом вивчення багатьох напрямів сучасного мовознавства, зокрема комунікативної лінгвістики, психолінгвістики, теорії мовленнєвої діяльності, соціолінгвістики, етнолінгвістики тощо. Висвітлення проблеми комунікації, ii компонентів та явищ крізь призму психічних, соціокультурних і мовних складових неодноразово ставало предметом наукових розвідок у сучасному мовознавстві (Ф. Бацевич, А. Бочкарьов, В. Зінченко, В. Кашкін, В. Конецька, В. Красних, М. Макаров, О. Селіванова, І. Семененко, О. Семенюк, К. Серажим, М. Серьогіна, І. Стернін, Н. Формановська та ін.). Значне місце в цих дослідженнях належить характеристиці стратегій і тактик успішного міжособистісного й міжкультурного спілкування, адже успішна комунікація $\epsilon$ запорукою взаєморозуміння між співрозмовниками, встановлення доброзичливих дружніх або плідних партнерських відносин. Важлива роль у цьому аспекті належить дотриманню комунікативних правил і табу, сформованих у певній лінгвоспільноті.

Явище табу в комунікації викликає посилений інтерес учених, про що свідчать численні лінгвістичні студії українських i зарубіжних фахівців (К. Алан, О. Бабаєва, Ф. Бацевич, К. Берідж, Х. Вебстер, Р. Газізов, Дж. Глізон, Т. Джей, Д. Зеленін, Н. Мечковська, В. Півнюк, Я. Попова, А. Редкліф-Браун, О. Рутер, О. Смолянцева, Л. Фроляк, К. Харіс, Г. Шредер та ін.). Закономірною постає потреба з'ясування впливу табу на комунікацію загалом, виявлення типових механізмів дотримання табу в процесі спілкування й оцінки його результативності.

Традиційно вважають, що термін табу в науковий обіг уведено англійським релігієзнавцем й етнологом Дж.Фрезером у його праці «Золота гілка». Нині це поняття набуває нового звучання й уживається для позначення заборони на певні предмети й види діяльності, зумовленої різними екстралінгвальними чинниками. 3 позиції мовознавства, на нашу думку, табу являє собою будь-яку заборону або ситуативне обмеження на вживання в мовленні певних мовних одиниць (звуків, букв, лексем, словосполучень, несегментних фонетичних одиниць - тону, висоти голосу, тембру, інтонації тощо), тем, тактик, а також уникання спілкування 3 () Ю. В. Єловська, 2015. 


\section{СТРУКТУРА І СЕМАНТИКА МОВНИХ ОДИНИЦЬ}

окремими особами, зумовлене різними екстралінгвальними чинниками, зокрема релігійно-магічними, суспільно-політичними, культурними, морально-етичними тощо.

Аналіз фактичного матеріалу дає підстави розмежувати загал комунікативних ситуацій на комунікативні акти 3 порушенням табу й ті, що характеризуються дотриманням існуючих заборон. Особливе зацікавлення викликають комунікативні ситуації з неповним дотриманням табу й наслідки такої комунікативної взаємодії. Під комунікативними ситуаціями з неповним дотриманням табу розуміємо комунікативні акти, де виявляємо часткове порушення заборони одним або кількома мовцями за рахунок уживання різних способів непрямого називання заборонених концептів, які реалізуються здебільшого за допомогою засобів евфемізації, графічної, іконічної чи паралінгвальної словозаміни, i покликаних створювати лише асоціативні зв'язки з табуйованим денотатом.

Серед опосередкованих засобів номінації табуйованих денотатів чільне місце належить процесам евфемізації. А. Кацев зазначає, що явище евфемії завжди вмотивоване певним табу, перебуває з ним у симетричних відношеннях i виступає його прямим наслідком. Хоча науковець підкреслює, що результатами табу поряд із евфемізмами стають замовчування (відсутність матеріального вираження лексеми чи словосполучення на позначення табу, про яке йшлося вище) й параевфемія (заміна табу невербальними засобами) [3, с. 16-17]. Однак у більшості випадків саме евфемія стає найпоширенішою стратегією уникнення прямого називання заборонених понять.

Пристаємо на позиції С. Обенга, К. Серажим й І. Решетарової, які пропонують включити засоби евфемії до більш широкої комунікативної стратегії ухильності. К. Серажим уважає евфемію й дисфемію особливими стратегіями використання слова, які становлять частину стратегії непрямого підходу. Непрямий підхід, запропонований С. Обенгом, відіграє важливу роль у керуванні вербальним конфліктом і конфронтацією, допомагає уникнути кризових ситуацій і комунікативних труднощів [5].

О. Селіванова під евфемізмом розуміє навмисну заміну мовного знака певного поняття описовим найменуванням або іншим знаком для усунення небажаних, надто різких, недостатньо ввічливих слів шляхом іхнього пом'якшення або шифрування через заборону, зумовлену соціально-політичними, історично-культурними, релігійними, етичними й естетичними чинниками [4, с. 135]. Обов'язковою умовою евфемії, на думку К. Серажим, $є$ встановлення у свідомості мовця асоціативних зв'язків між денотатом, пряме значення якого табуюється, і денотатом, 3 
яким виникає асоціація [5]. Розглянемо детальніше способи реалізації непрямого називання заборон. Проаналізований фактичний матеріал показує, що основним способом евфемізації табуйованих номенів стає лексико-семантична трансформація значень, меншу частину складають морфологічні й графічні способи уникнення заборонених назв.

Лексико-семантична група евфемістичних субститутів табу в українському персональному дискурсі загалом представлена групами метафоричних i метонімічних виразів, а також перифразами, які покликані маскувати негативний табуйований денотат. Особливо яскраво процес евфемізації спостерігаємо на рівні мовних, зокрема лексичних і тематичних табу. Розглянемо ілюстрації, що містять евфемістичні замінники повністю або частково табуйованих явищ.

У творі І. Котляревського «Енеїда» знаходимо чимало прикладів заміни лексем «померти» чи «вбити» описовими метафоричними й метонімічними конструкціями та перифразами: Вслід за коп'єм стрілу пускає і просто Тагові в висок; Душа із тіла вилітає, на жовтий пада труп пісок. ... Давайте вашого гульвісу, я вмиг його одправлю к бісу, $і$ вас подавимо, як мух... Пожди, от зараз почастую, із тебе виб'ю душу злую... Як б’ю я брат твій теє знає, ходи, тобі вкручу хвоста... Еней не милуя чванливих, в Мезентія всадив палаш; дух вискочив в словах лайливих, пішов до чорта на шабаш... Душа рутульська полетіла до пекла, хоть $i$ не хотіла (3, с. 147, $155,158,177,206)$. На особливу увагу в поданому текстовому уривку заслуговують лексеми $\partial y x$ і душа, наявність яких символізує життєдайну силу людини. Дух постає сутністю, що бере участь у житті природи і людини, виступає посередником між душею i тілом, $є$ своєрідною свідомістю душі. Душа, за релігійними уявленнями українців, - безсмертна, нематеріальна основа в людині, що становить сутність іï життя, яка по смерті відділяється від тіла [1, с. 208-209]. Очевидно, тому в зазначених ілюстраціях дієслова вмирати або убивати замінюються конструкціями на позначення виходу душі чи духу з тіла (Душа із тіла вилітає, виб'ю душу злую, дух вискочив), що означає відсутність життєдайної сили в людині, тобто іï смерть. На відміну від цих евфемістичних конструкцій, які характеризуємо як нейтральні, фразема вкручу хвоста має дисфемістичну знижену згрубілу оцінку, хоч і репрезентує наміри мовця фізично нашкодити опонентові та позбавити його життя. Припускаємо, що подані перифрази використовуються, щоб оминути пряме називання смерті людини, відповідно до існуючого у свідомості українців табу, й уникнути небажаного негативного ефекту від уживання відповідної прямої лексеми.

Замість заборонених понять уживають лексеми-замінники 3 ๑ Ю. В. Єловська, 2015. 


\section{СТРУКТУРА І СЕМАНТИКА МОВНИХ ОДИНИЦЬ}

протилежною антонімічною конотацією, інші частини мови, зокрема займенники й субстантивовані прикметники.

У розмові героїв п’єси І. Котляревського «Москаль-чарівник» натрапляємо на багато замінників прямого називання нечистої сили через перифрази із займенниковим компонентом на позначення чорта:

Солдат (сміється). Чево ж вы испугались? Я вам зла не сделаю

Михайло. Може, накладаєи з тим, щио живе в болоті?...

Солдат. Хотите ли, я покажу вам стариова, с которым все делаю?

Михайло. Стариого? Це б того, - мио греблі рве?

Тетяна. Цур йому! Це б того, щчо - не при хаті згадуючи? (Плюється) (3, с. 184).

Перифрази представників нечистої сили, зокрема чорта, не обмежуються вживанням лише конструкцій iз займенниковим компонентом: той, щзо живе в болоті; той, щуо греблі рве; той, щзо, не при хаті згадуючи. Евфемізмами стають також субстантивовані прикметники (куиий, нечистий, поганий, лихий, лисий) і власні назви (Гнат безп'ятий, турецьький син) [2, с. 89, 92-96]. До причин умисного намагання обійти це табу зараховуємо передусім вірування в те, що саме називання певного слова може викликати те явище, з яким воно пов'язане [8, с. 147].

3 тих самих причин з'являються лексеми-замінники прямих номінацій загалом нетабуйованих предметів чи дій. Так, наприклад, українські пілоти й актори театру замість слова «останній» кажуть «крайній», щоб їхній наступний рейс або виступ не став останнім у житті. Електрики замінюють слово «горить» на «світить», коли говорять про роботу освітлення. Серед пожежників не прийнято говорити один одному: «Не горіть» перед зміною чергувань, а, навпаки, бажати «сухих рукавів». Крім того, пожежники ніколи не прощаються і зазвичай кажуть «Не прощаємося», щоб не накликати терміновий виклик. Лікарі ніколи не кажуть колегам перед нічним чергуванням «Добраніч», інакше нічна зміна буде дуже важкою. Водії ніколи не відповідають на запитання «Коли приїдеш?» або «Куди їдеш?», замість них вони послуговуються питальною формулою «Де їдеш?» та відповіддюоберегом «Коли приїду, тодi й скажу», щоб убезпечити себе в дорозі. Машиністи бурового устаткування, які працюють у кар'єрах, перш ніж розпочати зміну, ніколи не говорять приладам «Як справи?», інакше обов'язково щось зламається. Своєрідним замовлянням на подальший успішний робочий день вони вважають промовляння до машин фрази «Добридень, любий», аби бурові установки працювали без збоїв.

Нині значного поширення набуває спілкування в мережі Інтернет, яке, хоч і підпорядковується певним правилам, проте не визначається їх 
суворим дотриманням. Адміністрація багатьох сайтів закликає Інтеренетспівтовариство бути взаємоввічливими й толерантними, не порушувати правила, установлені для підтримки інтелігентної дискусії на сторінках видань. Із-поміж них найбільш загальними $\epsilon$ такі: 1) забороняється розпалювати міжнаціональну ворожнечу; 2) виявляти ознаки дискримінації за расовою, етнічною чи іншою ознакою; 3) закликати до екстремізму, сепаратизму, тероризму або інших деструктивних дій; 4) погрожувати чи ображати журналістів, коментаторів, співробітників редакції, відомих особистостей; 5) уживати нецензурну лексику; розміщувати неправдиву або неперевірену інформацію, спам, безглузді коментарі або такі, що містять тільки спеціальні символи або перенасичені ними тощо (2). В іншому разі Інтернет-користувачі позбавляються можливості додавати свої коментарі чи брати участь в обговоренні поточних тем. Редакції багатьох Інтернет-видань і блогів залишають за собою право видаляти коментарі, які порушують політику редакції або правила коментування.

Однак підкреслимо, що саме в Інтернет-спілкуванні фіксуємо велику кількість фактичних порушень установлених правил. Табуйована лексика маскується за допомогою графічних знаків (крапки, дефіс, зірочки, зайві пробіли, друкарські символи, латинські літери тощо), буквозаміни, абревіатур, перифразів. Установлені банерні програми, маючи реєстр заборонених лінгвоодиниць, не ідентифікують такі новоутворення як заборонені, а тому ці коментарі з'являються у стрічці повідомлень.

У запропонованих ілюстраціях репрезентовано формальне уникнення порушення табу, більшість яких - це різноманітні інвективні й жаргонні вислови на позначення окремих об'єктів, осіб, груп людей, територій, які маскуються через графічні словозміни табуйованих мовних одиниць (латинські літери, друкарські знаки - дефіс, знак електронної пошти, зірочки, крапки, додаткові пробіли тощо): ВВД 08.11.2013 16:21 Москалі радуються свойм кіно. А воно хіба у них є? Tyfma. Сміх і позор <...>. (5); За такі гроші та таке лйно, яке виробляють кончені кащапи можна і в себе дома ліпити (5). Лексеми Tyfma, л@йно яскраво ілюструють бажання авторів коментарів надати більшої експресивності своїм висловлюванням через умисне вживання заборонених лінгвоодиниць.

Незначна частина прикладів ілюструє вживання антифразиса задля висловлення негативної оцінки певних явищ, об'єктів, осіб й одночасно дотримання встановлених адміністраторами табу. Розглянемо такі ілюстрації: Оче чудова ілюстрація «роботи» опоз. блоку! хай люди знають, які вони брехливі «шкідники»! хоча, закохані у них і на це закриють очі... проголосують на місиевих виборах... не дай Боже! (4); Кожний день ๑ Ю. В. Єловська, 2015. 
обстріли. Кожний день вбиті патріоти. «Гумконвой» за «гумконвоєм», важкі озброєння не відводяться. Танки, як і раніше «продаються в воєнторгах», провокації та погрози...(4).

Автор першого коментаря, вживаючи слово робота в лапках, підкреслює бездіяльність і нездарність урядовців, які представляють Опозиційний блок. У наведеній ілюстрації фіксуємо зміну прямого значення слова робота. Первинна семантика «дія, коло занять, обов'язків, справа, діло, чиєсь виконання чого-небудь, чийсь труд, працьовитість» [6, с. 587] набуває нової негативної конотації, а саме «лінощі, ледарство (відсутність бажання працювати, робити що-небудь; неробство)» [6, с. 519]. У другому контексті вживане скорочення гумконвой (гуманітарний конвой - гуманітарна допомога (продовольство, одяг, ліки тощо) постраждалим від бойових дій, яка і супроводжується й охороняється групою озброєних людей до прибуття іiі за відповідним призначенням [6, с. 257]) отримує зовсім протилежне значення, а саме надання систем озброєння, боєприпасів або іншого устаткування проросійськи налаштованим терористичним угрупуванням, розміщеним на територіях Луганської та Донецької областей задля ведення бойових дій.

Розглянутий фактичний матеріал дає підставити твердити, що неповне дотримання табу в комунікативних ситуаціях виражається через застосування мовцями різних засобів евфемізації певної частини або всього інформаційного повідомлення. Серед найбільш уживаних способів непрямого порушення табу переважають лексико-семантичні, а саме метафоричні, метонімічні й перифрастичні конструкції. Дещо меншою за обсягом є група морфо-графічніх способів заміщення, як-от буквозаміна графічними символами. Зафіксовані поодинокі приклади антифразису свідчать про периферійне положення цього способу маскування табуйованого об'єкта, явища, особи тощо. 3-поміж чинників, які спонукають мовців вдаватися в процесі комунікації до непрямої номінації та словозаміни, виокремлюємо прагнення дотримуватися встановлених заборон, зберігати своє «соціальне обличчя» та «соціальне обличчя» інших комунікантів, бажання до самозбереження, аби не викликати негативні наслідки необачного слововживання, а також намір словесно виражати власні психоемоційні стани й настрої. Результатами використання засобів евфемізації $\epsilon$ дотримання принципів увічливості й кооперації та можливість до подальшого спілкування. Однак у деяких комунікативних ситуаціях розшифрування евфемістичних замінників потребує додаткових національно-культурних знань, що суттєво утруднює комунікацію, якщо пресупозиції співрозмовників не збігаються. 


\section{Література}

1. Жайворонок В. В. Знаки української етнокультури : [словник-довідник] / В. В. Жайворонок. - К. : Довіра, 2006. - 703 с.

2. Зеленин Д. К. Табу слов у народов Восточной Европы и Северной Азии/ Д. К. Зеленин // Сб. музея антропологии и этнографии. $-1929 .-$ Т. VIII. -152 с.

3. Кацев А. М. Языковые табу эвфемия : [учеб. пособие к спецкурсу] / А. М. Кацев. - Л. : ЛГПИ им. А. И. Герцена, 1988. -80 с.

4. Селіванова О. О. Сучасна лінгвістика: термінологічна енциклопедія/ О. О. Селіванова. - Полтава : Довкілля. - К., 2006. - 716 с.

5. Серажим К. Евфемізація у політичному дискурсі [Електронний ресурс]/ К. Серажим // Стиль і текст. - 2004. - Вип. 5. - Режим доступу : http:/journlib.univ.kiev.ua

6. Словник української мови : в 11-и т. / [гол. ред. І. К. Білодід]. - К. : Наукова думка, 1970-1980.

7. Ставицька Л. О. Український жаргон : [словник] / Л. О. Ставицька. - К. : Критика, 2005. - 496 с.

8. Ужченко В. Д. Фразеологія сучасної української мови : [посібник]./ В. Д. Ужченко, Д. В. Ужченко. - Луганськ : Альма-матер, 2005. - 400 с.

\section{Список використаних джерел}

1. Вовчок М. Вибрані твори / М. Вовчок. - К. : Шанс, 2013. -224 с.

2. Інформаційне агентство УНІАН [Електронний ресурс]. - Режим доступу : http://www.unian.ua

3. Котляревський І. П. Повне зібрання творів / І. П. Котляревський. - К. : Наукова думка, $1969 .-510 \mathrm{c.}$

4. Українська правда [Електронний ресурс]. - Режим доступу : http://www.pravda.com.ua

5. Gazeta.ua [Електронний pecypc]. - Режим доступу : http://gazeta.ua

Стаття надійшла до редакиії 16.06.2015 p. 